\title{
Supporting E-learning in Teaching English as a foreign language in Higher Education
}

\author{
DR.Yasmin El-Sayed Kamil Mohamed \\ EFL Lecturer at the Faculty of Education- \\ Aswan University
}




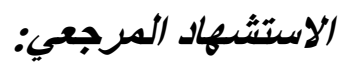

Mohamed, Yasmin El-Sayed Kamil(2017) Supporting E-learning in Teaching English as a foreign language in Higher Education/ Yasmin El-Sayed Kamil Mohamed.- Journal of Distance Learning and Open Learning .- Vol 6, Issue 11 (June-December).-PP.73-87 


\section{Introduction}

The use of network technology to deliver training is the latest trend in the training and development industry and has been heralded as the 'e-learning revolution.

E-learning is part of the biggest change in the way our species conducts training since the invention of the chalkboard or perhaps the alphabet. The development of computers and electronic communications has removed barriers of space and time. We can obtain and deliver knowledge anytime anywhere. (Horton, 2000: 6)

In an effort to indicate the role of e-learning in higher education and the field of language teaching, this paper reviews research literature on e-learning. Specific attention is given to why organizations use e-learning, what the potential drawbacks to e-learning are, what we know from research about e-learning and what the future of e-learning may hold.

This paper aims at presenting a comprehensive review of the research literature on e-learning and discussing answers to the following questions:

(1) What is e-learning and how is it being used in higher education organizations?

(2) Why are organizations using e-learning?

(3) What are potential drawbacks of using e-learning? 


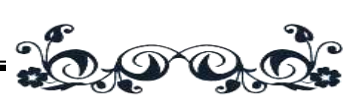

(4) What has empirical research found regarding e-learning effectiveness, efficiency, attrition, and appeal to learners?

Definitions of e-learning

A multitude of definitions of e-Learning already exists in literature.

For many authors the adoption of electronic media in a learning scenario is already sufficient to constitute e-Learning. This definition is clearly too broad. For example the use of a microphone during a lecture should be excluded by a proper definition from being e-Learning. So, the simple use of electronic media is not enough. (E-Learning Consultant, 2003)

An alternative definition of e-Learning has been that eLearning is aggregation of all kind of learning which use the computer for medial support of the learning process. Similarly, Baumgartner, Häfele and Maier-Häfele (2001) suggest that eLearning is the general term for all kind of software supported learning. Both attempts are not very useful because they are also too loose and do not demand enough.

E-learning can be defined in this paper as the use of computer network technology, mainly over an intranet or through the Internet, to deliver information and instruction to individuals. 
E-Learning in Higher Education Environment

Despite the fact that e-Learning exists for a relatively long time, it is still in its infancy (Tavangarian, 2004)

Most e-learning in higher education environments today is asynchronous in nature. Asynchronous e-learning refers to elearning that is 'pre-recorded' or available to employees at any time of the day, potentially from any location (Rosenberg, 2001).

Less common is synchronous e-learning in higher education environment, or e-learning that is 'live' and that requires all learners to be in front of their computers at the same time. While these kinds of training seem quite distinct from each other and from instructor-led training, the distinction between them is often blurred because many companies use a mix of delivery options for their classes.

Blended classes, or 'blended learning,' use some combination of technology and classroom based learning and is becoming a very popular form of training. (Elliott, 2002; Zenger and Uehlein, 2001).

As with asynchronous e-learning, there is a continuum of types of synchronous e-learning. The most basic type of synchronous learning involves real time 'chat' sessions where employees $\log$ on at the same time to discuss training topics. 


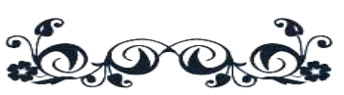

A more complex type is a synchronous session where learners from diverse locations log into the training at a set time, and an instructor facilitates a discussion while showing slides or writing on a 'whiteboard' that appears on the computer screens of the learners. During these sessions, learners can ask questions, sometimes verbally, of the instructor.

Why should higher education environment use e-learning?

Higher education institutions are choosing e-learning for a variety of reasons framing the advantages of using e-learning. These benefits can be summarized in the following:

1. E-learning provides consistent, worldwide training: Elearning appeals to higher education institutions that have a strong need or desire to deliver consistent training across multiple locations.

2. E-learning reduces delivery cycle time: higher education institutions also use e-learning when they are pushed to deliver training to many learners quickly. Because elearning classes are not constrained by instructor and classroom capacity, more learners can be trained in less time.

3. E-learning increases learner convenience. Another benefit of e-learning is increased learner convenience. Provided that they have the required technology, learners have access to asynchronous e-learning at any time. To facilitate such 


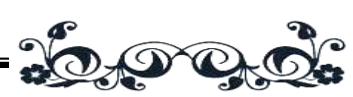

just-in-time use of training, synchronous courses are frequently archived so that they can be accessed when needed by learners.

4. E-learning reduces information overload: E-learning also has the potential to manage the growth in the amount of information that learners in higher education stage need to learn. This growth has often led to information overload during training and learning, resulting in ineffective training when learners cannot retain all of the information presented to them. By conducting part of the training asynchronously, part of it synchronously, and only the most interactive part in a classroom, the information can be delivered over a longer period of time. This is thought to improve retention.

5. E-learning improves tracking: Another potential advantage of e-learning in higher education environments is their ability to track learner activities and mastery of the material. Many training and instruction institutions, before elearning, did not track such data because of the effort required to do so. With e-learning, tracking and storing can be automated. This is particularly beneficial when training is required for compliance.

6. E-learning environments lower expenses: Most of the international higher education institutions are also turning to e-learning as a cost-saving measure, particularly when they 


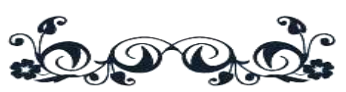

want to reduce travel and classroom costs, and time off-thejob, associated with off-site training.

\section{Potential drawbacks of using e-learning}

1. The Up-front cost of applying e-learning in higher learning institutions: The Up-front cost was the most frequently mentioned drawback of applying e-learning in higher education institutions. Specific costs include development costs to design and build the actual courses as well as hardware and software costs to allow users to access the training effectively.

2. The lack of interaction among trainees in many higher education e-learning courses: previous literature and research studies show that the lack of peer-to-peer networking makes e-learning less attractive to its learners and potentially less useful.

3. The lack of other skills: the use of static and non-interactive e-learning in higher education stages may create a mindset that electronically-encoded. In other words, the concern is that top management will become preoccupied with the capability to push information and will forget that training involves more than information provision; it requires practice, feedback, and guidance, and more; learning other 


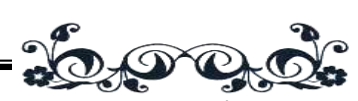

social skills like cooperation, social interaction and planning.

E-learning and Foreign language Instruction in higher education stage:

We live in a an age in which text messages, photos, audio and video files are transmitted from one cell phone to another in seconds, latest mobiles and iphones allow us to connect to the internet through wireless network; e-mails, instant messaging, chat rooms, UseNet groups, blogs and wikis have revolutionized the way we share information and communicate with each other.

Rapid evolution of these modern information communication technologies has greatly changed every aspect of life including language pedagogy, language learning and language use. The introduction of information communication technologies in language teaching has opened new horizons for language teachers to have more interactive and learner-centered classroom environment.

\section{Challenges and recommendations:}

In their continuous trials of following and using the modern trends in teaching English as a foreign language, language educators face a number of challenges in applying elearning in the higher education institutions. A wide number of 


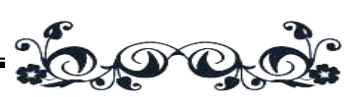

these challenges and strategies can broadly be categorized in three areas; technical, administrative and academic.

\section{Technical Challenges:}

There are several technical challenges that hamper instructors' as well as students' activities in an information communication technologies learning environment. "Lack of basic technical skills" of both students and teachers alike is one of the most frequently cited technical challenges in literature. Some staff members feel stressed and embarrassed for an exam which requires technical equipment of any sort". An unexpected technical issue, especially during an exam, further increases this stress.

Students' lack of digital competency is also considered another technical challenge that hinders their learning in an elearning environment along with the mechanical difficulties that interfere with their abilities to express their thoughts.

Some other challenges mentioned in previous studies are "crashing of system, fluctuation of electricity, slow internet, files corruption, suitable programs not being installed like graphics, animation or media players, etc". The studies suggest arranging extra classes or training workshops for both students and teachers to get the maximum advantage of the applying elearning in foreign language teaching in higher education. 


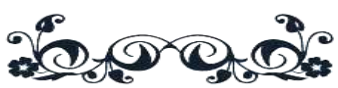

\section{Administrative Challenges:}

Administering an activity or an assessment which requires technological infrastructure is another significant challenge that faces institutions of higher education. "Lack of elearning resources for all classrooms" and "lack of full-time staff to monitor the electronic equipments" are the main challenges cited in related studies.

As a strategy, the previous studies suggest that teachers should make sure that an adequate amount of classroom learning and independent e-learning is used in advance of an electronic-based assessment. Otherwise, it is unfair for the medium to be used as a testing tool.

\section{Pedagogical Challenges:}

The previous two challenges make the task of foreign language teaching and learning more challenging. The foreign language trainers' lack of knowledge to design language tasks with technology and lack of confidence to use technology while teaching is considered as the basic pedagogical challenges that need to be addressed to enhance ICT application in foreign language teaching classes.

Spending a substantial amount of time and effort restructuring web-based language activities to adopt for online delivery for students with very limited educational background 


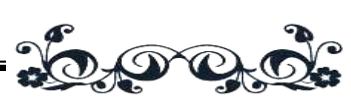

and digital competencies is reported as another pedagogical challenge that might face e-learning environments in higher education. This sometimes goes at the expenses of focusing on building the target language skills.

The previous studies recommend building the lecturers' and the learners' ICT skills and adding up the bank of elearning resources in order to facilitate language educators in multitude of ways such as designing web-based language activities, tailoring language tasks to suit module learning outcomes, assessing students' language skills electronically, etc. When introducing new technology to the classroom, as elaborated by a keen e-learning practitioner, it is critical to ensure that there is a sound pedagogy behind the move, not just a desire to use new toys. Students can be overwhelmed with too much technology, or confused by badly used or badly setup technology.

One more pedagogical challenge is that Lecturers confront another difficulty of monitoring learners' progress in an online activity. Some students feel that the networked conversation are disorganized, and even feel frustrated because of the quick evolution of ideas and multiplicity of entries on the computer screen simultaneously". 
Most of the recent studies recommend educators in higher education institution to apply the blended form of learning which equips traditional language teachers with a variety of e-learning tools such as Discussion Boards, Classroom Response System (CRS), Voting Pads, Moodle/Virtual Learning Environment, Blogs, etc. Students only need quite a bit of encouragement to actually use these technological sophistications and teachers need a bit of momentum built up on them before they become an integral part of learning process". 


\section{References}

1. Brown, K. G. and Ford, J. K. (2002), Using computer technology in training: Building an infrastructure for learning. In K. Kraiger (ed.), Creating, Implementing, and Managing Effective Training and Development (pp. 192-233). Mahwah, NJ: Jossey-Bass.

2. Clark, R. E. (1994), Media will never influence learning. Educational Technology Research and Development, 42, 21-9.

3. E-Learning Consultant (2003) Glossary. Address: http://www.eLearningsite.com/elearning/glossary/glossary.htm.

4. Elliott, M. (2002), Blended learning: The magic is in the mix. In A. Rossett (ed.), The ASTD E-learning Handbook, (pp. 58-63). New York: McGraw-Hill.

5. Horton, W. (2000), Designing Web-based Training. New York: John Wiley and Sons.

6. Rosenberg, M. J. (2001), E-learning: Strategies for delivering knowledge in the digital age, New York: McGraw-Hill.

7. Sun, L. and Williams, S. and Liu, K. (2003) Knowledge Construction in e-Learning: designing an e-Learning environment. Proceedings of 5th International Conference on Enterprise Information Systems, Angers, France

8. Tavangarian, Is e-Learning the Solution for Individual Learning?, Electronic Journal of e-Learning, Volume 2, Issue 2, 2004 (273280)

9. Zenger, J. and Uehlein, C. (2001), Why blended will win. T+D, 55, August, 54-60.

10. Laurillard, D. (1995) Multimedia and the changing experience of the learner. British Journal of Educational Technology, Vol. 26(3). p. 179-189.

11. Baker, G. (1992), Application report: Instructional design of a computer-assisted work-related literacy program, Journal of Computer-based Instruction, 19, 33-6.

12. Brown, K. G. (2001), Using computers to deliver training: Which employees learn and why? Personnel Psychology, 54, 271-96. 
13. Brown, K. G. and Ford, J. K. (2002), Using computer technology in training: Building an infrastructure for learning. In K. Kraiger (ed.), Creating, Implementing, and Managing Effective Training and Development (pp. 192-233). Mahwah, NJ: Jossey-Bass

14. Dobbs, K. (2002), The state of online learning - what the online world needs now: Quality. In A. Rossett (ed.), The ASTD Elearning Handbook, (pp. 357-72). New York: McGraw-Hill.

15. Horton, W. (2000), Designing Web-based Training. New York: John Wiley and Sons. 